\title{
The Prevalence of Persistent Metopic Sutures Comparing the Nepalese Bone Collection with Korean Bone Collection
}

\author{
Prevalencia de Suturas Metópicas Persistentes que Comparan una \\ Colección de Huesos Nepaleses con una Colección de Huesos Coreanos
}

\author{
Dhiraj Maskey; Ajaya Jang Kunwar'; Krishna Deo Sharma² \& Myeung Ju Kim³
}

MASKEY, D.; KUNWAR, A. J.; SHARMA, K. D. \& KIM, M. J. The prevalence of persistent metopic sutures comparing the Nepalese bone collection with Korean bone collection. Int. J. Morphol., 38(5):1376-1380, 2020.

SUMMARY: Metopic suture can be visualized from the nasion to the bregma along the arch of the frontal bone in mid-sagittal plane. Persistent metopic suture normally closing between 1 st and 2nd year of life has also been related with ethnicity. The present study reports the presence of complete and incomplete metopic sutures in Nepalese and Korean population skulls which helps to shed light on its incidence rate. Out of 121 adult skulls in Nepalese population, metopic suture was found to be present in 33 skulls. Incomplete metopic sutures showed variations of morphology, like linear $(6.61 \%)$, V-shaped $(8.26 \%)$ and double incomplete (10.74 \%) and two cases with complete metopic suture, which showed variation in interdigitation between its anterior and posterior ends. Korean population showed metopic suture to be present in 8 skulls out of 104 with metopism in 3 skulls. Incomplete metopic sutures like double incomplete $(1.92 \%)$ and linear $(2.88 \%)$ were also noted. Alterations to local strains could be the contributing factor for such variation and complexity of interdigitation, which occur during the growth of the braincase. The knowledge of the metopic suture and its variations according to ethnicity is important and should be considered to prevent wrong diagnosis. The presence of different types of metopic sutures as reported by the present study provides informative value on the presence and variation of such sutures in population depending on ethnicity and ought to be helpful in diagnostic sequences in emergency setting.

KEY WORDS: Korean; Nepalese; Skull; Metopic suture; Metopism.

\section{INTRODUCTION}

The cranial sutures have been extensively studied due to its medical and surgical significance. Metopic suture is a dentate suture comprising of dense connective tissue, which can be visualized from the nasion to the bregma along the arch of the frontal bone in mid-sagittal plane. It undergoes intramembranous ossification from two primary centers usually appearing by the end of second month of fetal life (Mayo Gòss, 1988), initially fusing at the inner face of the skull (Moore, 1994). Metopic suture is the first suture to close although various studies have depicted different time for closure ranging from between first and second year of life (Keith, 1948) to sixth and eight year (Ajmani et al., 1983). Earlier closure of metopic suture leads to cranial morbid deformities known as scaphocephaly, a part of craniosynostosis. However, complete failure of the closure will result in persistence of the metopic suture known as metopism.
Metopism can be related to various causes, like abnormal growth of the cranial bones, pathologic metopism triggered by hydrocephalus, growth interruption, heterospecific factors, sexual influence, heredity, atavism, stenocrotaphia, plagiocephaly, scaphocephaly, mechanical causes and hormonal dysfunction (del Sol et al., 1989). Genetic influence is also a widely accepted factor for metopism (Torgersen, 1951).

Ethnic diversity is known to play a major role in the different incidence of the metopism (Mathijissen et al., 1996). Metopic suture has been reported to range from $0.8 \%$ to $15 \%$ across different populations (Woo, 1949; del Sol et al.; Baaten et al., 2003; Murlimangu et al., 2011, Nikolov \& Toneva, 2012). Highest incidence (del Sol et al.) of metopism has been reported in the Alpine skulls (63.2

${ }^{1}$ NeuroVIS, 110, Jiksan-ro, Cheonan-si, Chungcheongnam-do, South Korea.

${ }^{2}$ Department of Anatomy, Nepalese Army Institute of Health Sciences, Bhandarkhal, Kathmandu, Nepal.

${ }^{3}$ Department of Anatomy, Dankook University College of Medicine, Cheonan-si, Chungcheongnam-do, South Korea. 
\%) while the lowest (Bryce \& Young, 1917) has been known to be present in Australian and Scottish skulls (1.0\%).

The clinical importance on the identification of the metopic suture and its diversity among different human races are crucial, as its persistent presence can be mistaken for a cranial fracture in radiological images (del Sol et al.), or even for the sagittal suture (Ajmani et al.) and is also important for paleodemography and forensic science (Hauser et al., 1991). The person's ethnicity might contribute to the variation in persistence of metopic sutures. Keeping the importance of the persistent metopic suture and its variation in different population groups in mind, the present study reports the incidence of metopic suture in Nepalese and Korean populations making aware of the possible difference according to ethnicity.
Kathmandu and Maharajgunj Medical Campus, Institute of Medicine, Maharajgunj, Kathmandu ( $\mathrm{n}=121)$ and Dept of Human Anatomy, Dankook University College of Medicine, Cheonan, South Korea $(n=104)$. The analysis of the skulls and description of the metopic sutures were performed by macroscopic observation. All the skulls were properly cleaned out to identify persistent metopic suture before investigation. The skulls showing any visible abnormalities or signs of disease were excluded and age and sex of the skulls were not taken into consideration in this study. The persistent metopic suture in the frontal bone was thoroughly recorded the types of metopic suture as linear, single, V-shaped, bifurcated and double sutures in all cases (Agarwal et al., 1979; Ajmani et al.). The linear length of the metopic suture was measured as direct distance from nasion to bregma along the superior arch of the frontal bone in the mid-sagittal plane.

\section{MATERIAL AND METHOD}

Adult skulls for this study were obtained from the Dept of Human Anatomy of Nepalese Army Institute of Health Sciences - College Of Medicine (NAIHS-COM),

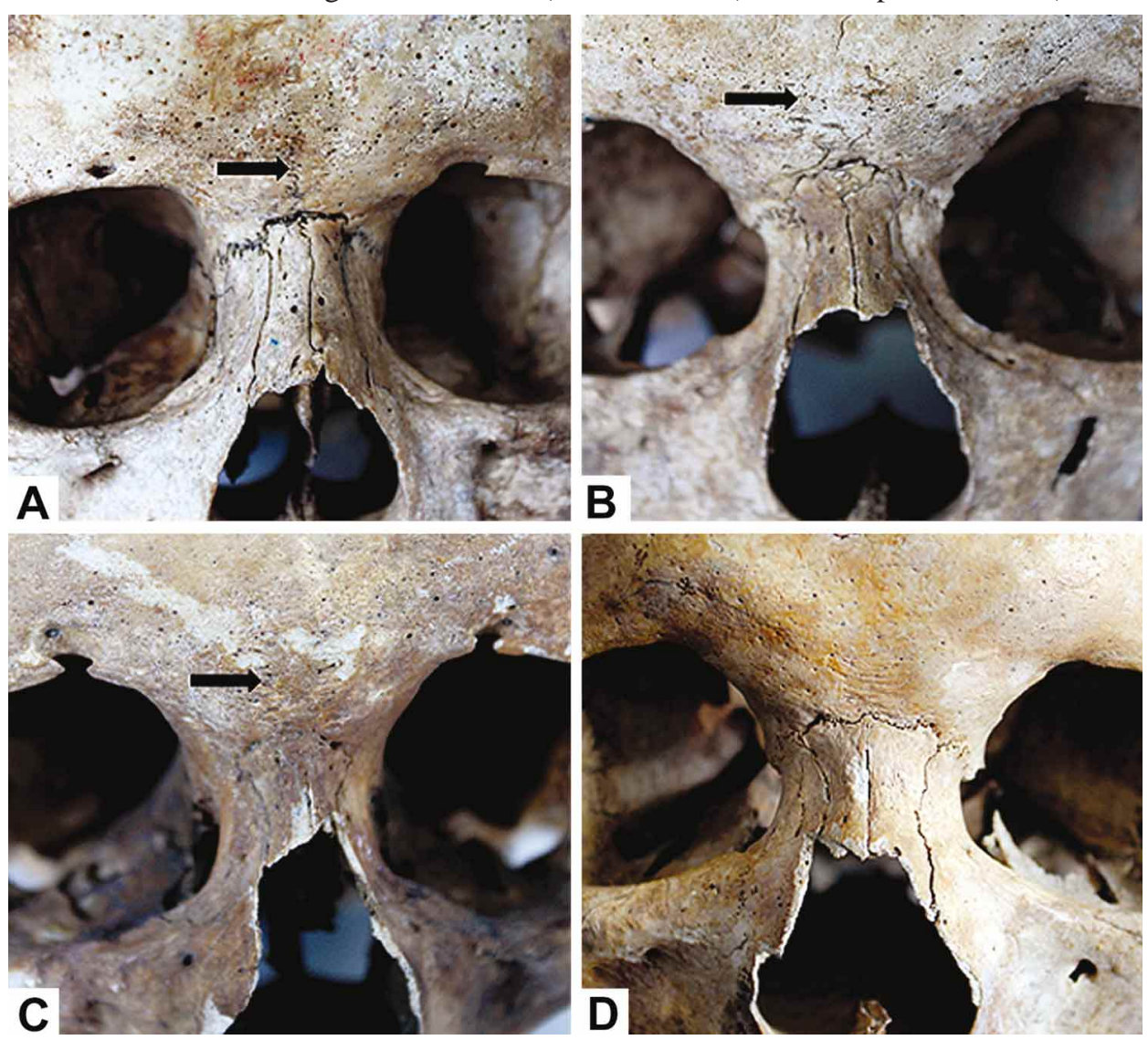

Fig. 1. Morphological variants of incomplete metopic sutures (arrows). A: Linear type, B: 'V' shaped suture, C: Double type, D: Absent metopic suture.

\section{RESULTS}

Metopic sutures in Nepalese population was noted to be present in 33(27.27\%) out of 121 skulls (Table I). Incomplete metopic sutures all present in the lower part of the frontal bone, was noted in $31(25.61 \%)$ skulls. Among the incomplete metopic sutures, $8(6.61 \%)$ were linear (Fig. 1A), 10 $(8.26 \%) \mathrm{V}$ shaped (Fig. 1B) and $13(10.74 \%)$ displayed double incomplete metopic suture (Fig. 1C). Metopism (Fig. 1A) was observed to be present in only $2(1.65 \%)$ skulls (Table I). 'U' shape, ' $\mathrm{H}$ ' shape and ' $\mathrm{N}$ ' shaped variation of metopic suture were not observed. Skulls from the Korean population demonstrated metopic suture in $8(7.69 \%)$ out of 104 skulls (Table I). Double incomplete metopic suture was noted in $2(1.92 \%)$ while $3(2.88 \%)$ had linear type of incomplete metopic suture. No other types of metopic sutures were observed. Complete metopism was noted in 3 $(2.88 \%)$ skulls (Table I). 


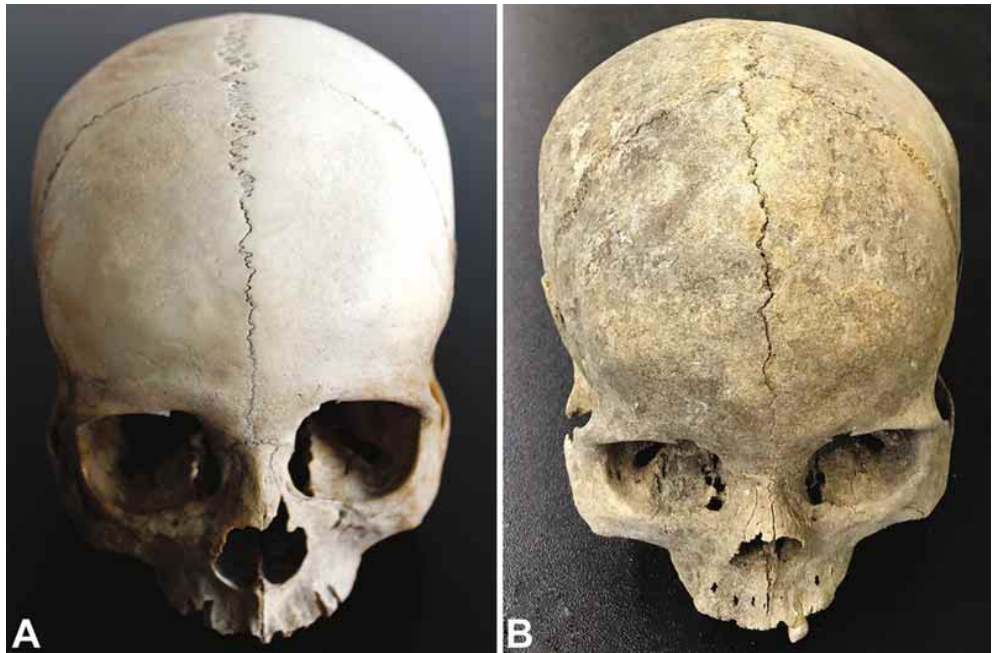

Fig. 2. Location of complete metopic suture (metopism) in the Nepalese (A) and Korean (B) human skull. Note the metopic suture extending from the nasion to the bregma.

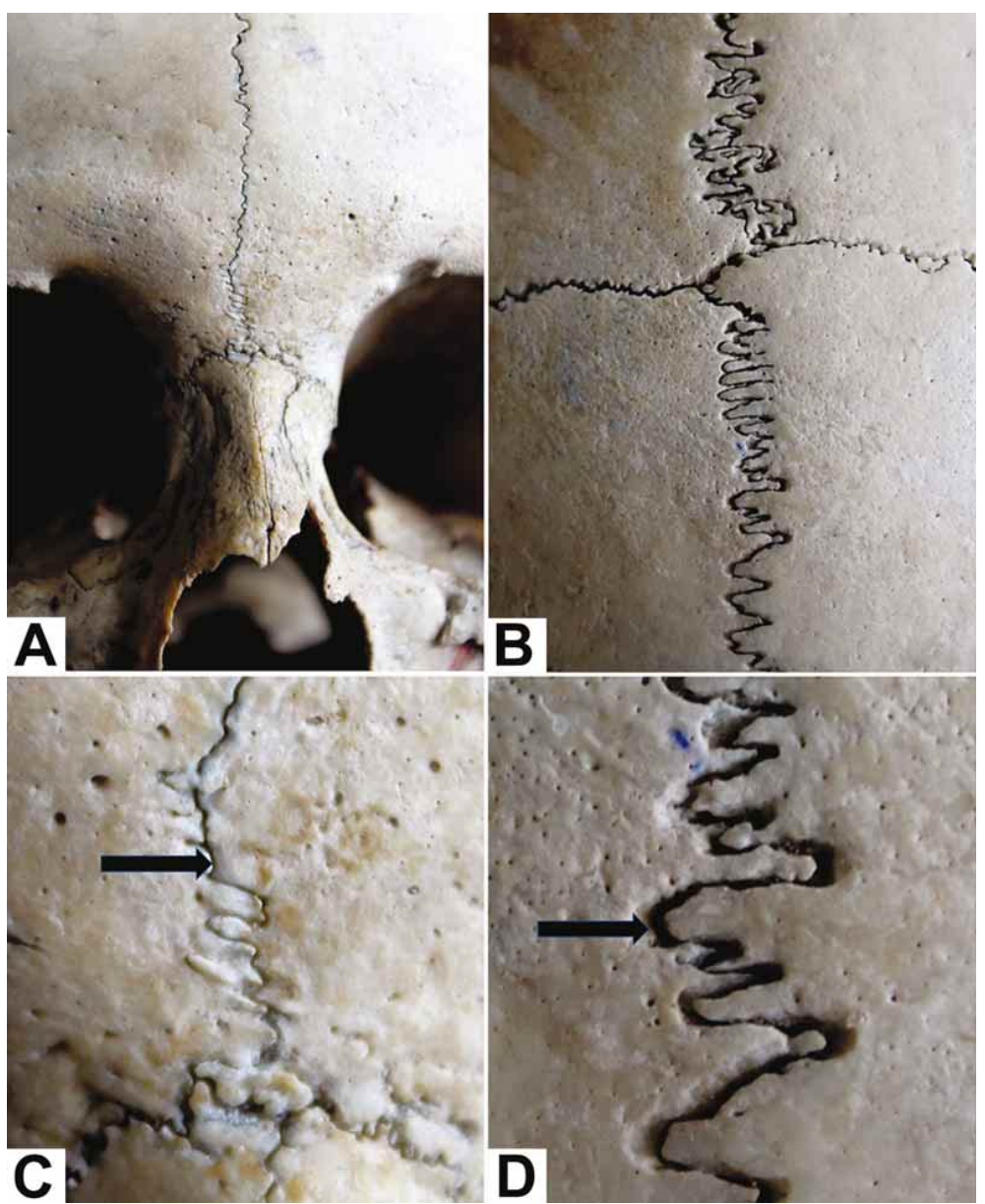

Fig. 3. Magnified image of the complete metopic suture (metopism). A\&B: Anterior end of the complete metopic suture with fine interdigitations. C\&D: Metopic suture is not meeting end to end with the sagittal suture at the bregma. Minute denticulations (arrow) were noted in the anterior end (C) while the posterior end (D) of the metopic suture (arrow) was highly convoluted.
Table I. The Incidence rate of metopic suture in Nepalese and Korean bone collection.

\begin{tabular}{lll}
\hline & Nepalese $(\mathrm{n}=121)$ & $\begin{array}{l}\text { Korean Population } \\
(\mathrm{n}=104)\end{array}$ \\
\hline Suture types & Number $(\%)$ & Number $(\%)$ \\
Metopism & $2(1.65 \%)$ & $3(2.88 \%)$ \\
Double incomplete & $13(10.74 \%)$ & $2(1.92 \%)$ \\
Linear & $8(6.61 \%)$ & $3(2.88 \%)$ \\
V Shaped & $10(8.26 \%)$ & 0 \\
Total metopic & $33(27.27 \%)$ & $8(7.69 \%)$ \\
\hline
\end{tabular}

Complete metopic suture was noted extending from nasion to bregma. The upper end of the metopic suture failed to meet the anterior end of the sagittal suture and deflecting towards the right side (Fig. 2). The pattern and complexity in the course of the complete metopic suture was noted to differ significantly between the anterior (extending from the nasion) (Figs. 3A and C) and posterior (beginning in the bregma) half (Figs. 3B and D). The anterior part (Figs. 3A and $\mathrm{C}$ ) of the metopic sutures was less complicated than the posterior part (Figs. 3B and D), which was highly convoluted. The posterior part was irregular and had rough projections while the anterior segment resembled a convoluted line with minute denticulations (Figs. 3B and D).

\section{DISCUSSION}

Metopic suture is normally present in the frontal bone of the fetus as an anterior extension of the sagittal suture from the nasion to the ventral part of the anterior fontanelle (Skrzat et al., 2004). The etiology of persistent metopic suture is still unclear, especially, as to why the fusion of the two frontal bones occurs while the other sutures in skull remains (Bilodi et al., 2003). The frontal bone of the fetus was departed as two by the sutural space, which is composed of fibrous tissue, and mesenchymal cells that are believed to be responsible for the growth of frontal bones and later differentiate either into bone or cartilage (Pritchard et al., 1956). The active bone resorption by osteoclasts may prevent the suture closure in the frontal bone that is normally carried out by the chondrocytes (Manzaranes et al., 1998). The role of the dura mater-suture complex in determining metopic suture patency has been discussed with animal models (Levine et al., 1998). It was indicated that some 
cytokines showed increased expression during active cranial suture fusion (Bademci et al., 2007).

In the present study, the difference in the shape of the suture was observed between the anterior and posterior part in metopism. Such a shape difference could be ascribed to the regional force exerted as different stress. Possibility of the posterior part of the metopic suture being subjected to greater function stress than the anterior part exists, due to which it has to resist stronger strains leading to an increase in interdigitation. This hypothesis is supported by the lower fractal dimension of the anterior part of the suture (Janusz et al., 2004) suggesting a decrease in the sutural complexity. The sustained effect of the metopic suture presence on the modifications of the skull shape has not been discussed in detail in the present study. due to lack of suitable amount of data. Comparative analysis of craniofacial morphology between metopic and non-metopic adult skull may give us with some meaningful data, but not considered in the present study.

The present study investigated the presence of metopic suture and its variation in Nepalese and Korean population. Previous study reported lower incidence of metopic suture $(11.46 \%)$ and its variations (Bilodi et al., 2004), however the present data showed higher incidence of metopic suture $(27.27 \%)$ and higher variations as well. The disparity in the two studies could partly be ascribed to the difference of compared sample size between the previous study ( $n=51$ skulls) and present study $(n=121$ skulls). Different study on Korean population reported the metopism in $8.3 \%$ from 91 skulls (Lee et al., 1989) which was higher than in the present study albeit the total number was slighter higher in the present study. Comparison between Nepalese and Korean skulls showed higher incidence of metopic suture in Nepalese as compared with Korean skull hinting towards significance of ethnicity with persistence metopic suture.

Persistence of metopic suture ranging from $1 \%$ to $12 \%$ of adult skull, which varied according to ethnicity, has been reported (Carolinberry \& Berry, 1967). Complete metopic suture was reported to be greatly less than incomplete one which was in line with the present study. Metopic suture incidence was reported to be $24.67 \%$ in Indian skulls (Das et al., 1973), 34.87\% in Nigerian skulls (Ajmani et al.), 4-5 \% in yellow races, 7-10 \% in Europeans (Breathnach, 1965) while another study showed $8.7 \%$ in Mongolian, $9.5 \%$ in Europeans, $1.2 \%$ in Africans and 1 $\%$ in Australians (Bryce \& Young). The above data along with the present findings in Nepalese and Korean population definitely shows the variation in the incidence of metopic suture according to ethnicity.
Although the persistent metopic suture was often dealt in anthropological studies, the report of it in clinical practice was extremely rare (Bademci et al.) and the pathological significance of it was also easily ignored in the clinicians. However, premature fusion of the metopic suture results in trigonocephaly and it has been calculated that this craniosynostosis stands at 400 per 1,000,000 births in humans (Zumpano et al., 1999). Maintenance of sutures in general has been suggested as a pre-condition for the continuous growth of the bones (Watzek et al., 1982) and as an indirect factor for the normal growth of the skull (Manzanares et al., 1988), however its persistence might mislead towards its misinterpretation as a cranial fracture in radiological images (del Sol et al.), or even for the sagittal suture (Ajmani et al.). Although incomplete metopic sutures are easily recognized on the organic piece (Baaten et al.), it can be mistaken for vertical fracture, as it is difficult to identify on the X-rays. Persistent metopic suture in head injury case might be erroneously misdiagnosed as vertical fracture. Information on metopic suture is also important for paleodemography and forensic medicine (Hauser et al.).

Ethnicity has been linked with genetic lineage (Torgersen) and suggestion of craniosysnostosis or even metopic suture's link with different ethnic group difference in gene cannot be ignored. This underlines the importance of having accurate information on the prevalence of metopic suture according to ethnicity. Their morphological details are important for the clinicians from radiological and surgical point of view; hence the possibility of incidence of metopic suture in relation with the patient's ethnicity should be taken into consideration while analyzing X-ray, CT and MRI films for clinical diagnosis of skull fractures and other skull related medical problems. Hence, the findings of the present study elucidate the presence of metopic suture in Nepalese and Korean population, helping to match up with other ethnic groups, which should be helpful in preventing confusion and wrong diagnosis in emergency situation stressing the importance of this anatomical condition and its relation to ethnicity.

MASKEY, D.; KUNWAR, A. J.; SHARMA, K. D. \& KIM, M. J. Prevalencia de suturas metópicas persistentes que comparan una colección de huesos nepaleses con una colección de huesos coreanos. Int. J. Morphol., 38 (5):1376-1380, 2020.

RESUMEN: La sutura metópica se puede visualizar desde nasión hasta el bregma a lo largo del arco del hueso frontal en el plano mediano sagital. La sutura metópica persistente que normalmente se cierra entre el primer y segundo año de vida, también se ha relacionado con el origen étnico. El presente estudio informa la presencia de suturas metópicas completas e incompletas en los cráneos de la población nepalesa y coreana, lo que además de entre- 
gar información sobre su tasa de incidencia. De 121 cráneos adultos en la población nepalesa, en 33 de ellos se encontró la sutura metópica. Las suturas metópicas incompletas mostraron variaciones de la morfología, como lineal $(6,61 \%)$, en forma de $\mathrm{V}(8,26 \%)$ y doble incompleta $(10,74 \%)$, además de dos casos con sutura metópica completa, que mostraron variación en la interdigitación entre sus extremos anterior y posterior. De los 104 cráneos de la población coreana en 8 se presentó la sutura metópica y en 3 metopismo. También se observaron suturas metópicas incompletas como doble incompleta $(1,92 \%)$ y lineal $(2,88 \%)$. Las alteraciones en las etnias locales podrían ser el factor contribuyente para tal variación y complejidad de la interdigitación, que ocurre durante el crecimiento de la cráneo. El conocimiento de la sutura metópica y sus variaciones según el origen étnico es importante y debe considerarse para prevenir un diagnóstico incorrecto. La presencia de diferentes tipos de suturas metópicas según lo informado en el estudio, proporciona un valor informativo sobre la presencia y la variación de tales suturas en la población, dependiendo de la etnia, y debería ser útil en las secuencias de diagnóstico en situaciones de emergencia.

\section{PALABRAS CLAVE: Coreano; Nepalés; Cráneo; Sutura metópica; Metopismo.}

\section{REFERENCES}

Ajmani, M. L.; Mittal, R. K. \& Jain, S. P. Incidence of the metopic suture in adult Nigerian skulls. J. Anat., 137(Pt. 1):177-83, 1983.

Baaten, P. J.; Haddad, M.; Abi-Nader, K.; Abi-Ghosn, A.; Al-Kutoubi, A. \& Jurjus, A. R. Incidence of metopism in the Lebanese population. Clin. Anat., 16(2):148-51, 2003.

Bademci, G.; Kendi, T. \& Agalar, F. Persistent metopic suture can mimic the skull fractures in the emergency setting? Neurocirugia, 18:238-40, 2007.

Breathnac, A. S. Frazer's Anatomy of the Human Skeleton. $6^{\text {th }}$ ed. London, Churchill, 1965.

Bryce, T. H. \& Young, M. Observations on metopism. J. Anat., 51(Pt. 2):15366, 1917.

Carolinberry, A. \& Berry, R. J. Epigenetic variation in the human cranium. J. Anat., 101(Pt. 2):361-79, 1967.

Das, A. C.; Saxena, R. C. \& Beg, M. A. Q. Incidence of Metopic suture in U. P. subjects. J. Anat. Soc. India, 22:140-3, 1973.

del Sol, M.; Binvignat, O.; Bolini, P. D. A. \& Prates, J. C. Metopismo no individuo brasileiro. Rev. Paul. Med., 107(2):105-7, 1989.

Hauser, G.; Manzi, G.; Vienna, A. \& De Stefano, G. F. Size and shape of human cranial sutures--A new scoring method. Am. J. Anat., 190(3):23144, 1991.

Lee, H. S.; Park, H. W. \& Kim, S. H. Metopic suture in Koreans. Korean J. Phys. Anthropol., 2(2):135-40, 1989.

Levine, J. P.; Bradley, J. P.; Roth, D. A.; McCarthy, J. G. \& Longaker, M. T. Studies in cranial suture biology: regional dura mater determines overlying suture biology. Plast. Reconstr. Surg., 101(6):1441-7, 1998.

Manzanares, M. C.; Goret-Nicaise, M. \& Dhem, A. Metopic sutural closure in the human skull. J. Anat., 161:203-15, 1998.
Mathijssen, I. M.; Vaandrager, J. M.; van der Meulen, J. C.; Pieterman, H.; Zonneveld, F. W.; Kreiborg, S. \& Vermeij-Keers, C. The role of bone centers in the pathogenesis of craniosynostosis: an embryologic approach using CT measurements in isolated craniosynostosis and apert and crouzon syndromes. Plast. Reconstr. Surg., 98(1):17-26, 1996.

Mayo Gòss, C. Gray Anatomia. 29 $9^{\text {th }}$ ed. São Paulo, Guanabara Koogan, 1988.

Moore, K. L. Anatomia Orientada Para a Clínica. $3^{\text {rd }}$ ed. Rio de Janeiro, Guanabara Koogan, 1994.

Murlimanju, B. V.; Prabhu, L. V.; Pai, M. M.; Goveas, A. A.; Dhananjaya, K. V. \& Somesh, M. S. Median frontal sutures - incidence, morphology and their surgical, radiological importance. Turk. Neurosurg., 21(4):48993, 2011.

Nikolova, S. \& Toneva, D. Frequency of metopic suture in male and female medieval cranial series. Acta Morphol. Anthropol., 19:250-2, 2012.

Pritchard, J. J.; Scott, J. H. \& Girgis, F. G. The structure and development of cranial and facial sutures. J. Anat., 90(Pt. 1):73-86, 1956.

Skrzat, J.; Walocha, J. \& Zawilinski, J. A note on the morphology of the metopic suture in the human skull. Folia Morphol. (Warsz.), 63(4):4814, 2004.

Torgersen, J. Hereditary factors in the sutural pattern of the skull. Acta Radiol., 36(5):374-82, 1951.

Watzek, G.; Grundschober, F.; Plenk Jr., H. \& Eschberger, J. Experimental investigations into the clinical significance of bone growth at viscerocranial sutures. J. Maxillofac. Surg., 10(2):61-79, 1982.

Woo, J. K. Racial and sexual differences in the frontal curvature and its relation to metopism. Am. J. Phys. Anthropol., 7(2):215-26, 1949.

Zumpano, M. P.; Carson, B. S.; Marsh, J. L.; Vanderkolk, C. A. \& Richsmeier, J. T. Three-dimensional morphological analysis of isolated metopic synostosis. Anat. Rec., 256(2):177-88, 1999.

Corresponding authors:

Myeung Ju Kim, M.D., Ph.D.

Department of Anatomy

Dankook University, College of Medicine

San\#29, Anseo-Dong

Cheonan,

Chungnam

SOUTH KOREA

E-mail: mjukim99@dankook.ac.kr

Dhiraj Maskey, Ph.D.

NeuroVIS

Cheonan SB Plaza

Jiksan-ro

Seobuk-gu

Cheonan-si

Chungnam

SOUTH KOREA

Email: dhiraj_mask@yahoo.com

Received: 30-03-2020

Accepted: 01-05-2020 